\title{
PARTICIPAR COM OS JOVENS E ADOLESCENTES DA EXPERIÊNCIA DE APROXIMAÇÃO COM O MUNDO ADULTO: O DESAFIO DA EDUCAÇÃO
}

\author{
Benedito Dielcio Moreira*
}

\begin{abstract}
RESUMO: Este trabalho discute as relaçóes que os jovens estudantes travam com o sistema midiático. Plenamente capazes de manipular as tecnologias midiáticas, eles trafegam entre e intra mídias com absoluta desenvoltura, com a intimidade de uma convivência cotidiana. Ocorre, entretanto, que todas as tecnologias de informaçáo e os conteúdos disponibilizados atuam como mediadores e co-construtores de realidades. Já, no outro extremo, no campo da recepção, encontra-se um receptor dotado de uma história e inserido em um contexto cultural distinto. Isso significa que há um processo de construção de realidades nos centros emissores, uma desconstrução no ato da recepção e novas versóes reconstruídas a partir da recepção e nas interaçóes que são feitas junto aos grupos sociais. Desse confronto, dos conteúdos midiáticos com uma dada realidade histórico-cultural do receptor, são gerados e compartilhados sentidos. As ideias aqui discutidas resultam de um estudo com jovens estudantes do primeiro ano do Ensino Médio de quatro escolas - duas públicas e duas privadas. Os estudantes responderam a um questionário, participaram de discussóes em sala de aula e de grupos focais. Dedico-me, portanto, a discutir o que é gerado na recepçáo, quais os conteúdos são relevantes, com quem são compartilhados e como a escola, enquanto espaço de socialização e aprendizagem, participa desse processo.
\end{abstract}

Palavras-chave: Jovens. Adolescentes. Mídias. Escola.

\section{PARTICIPATING WITH YOUNG ADULTS AND TEENAGERS IN THE EXPERIENCE OF APPROACHING THE ADULT WORLD: THE CHALLENGE OF EDUCATION}

ABSTRACT: In this paper we discuss the relations that young students have with the media world. Fully able to handle media technologies, young people travel between and intra media with absolute ease, with the intimacy of a daily coexistence. However, every information technology and the available content act as mediators and co-builders of realities. On the other extreme, in the field of reception, there is a

* Universidade Federal de Mato Grosso, Instituto de Linguagens, Departamento de Comunicação Social. Cuiabá, MT., Brasil. E-mail de contato: dielciomoreira@yahoo.com.br. 
recipient with a history and embedded in a distinctive cultural context. This means there is a process of construction of realities in issuing centers, a deconstruction in the act of reception and new versions are then rebuilt from the reception process and the interactions within social groups. From this confrontation of media content with a given cultural-historical reality of the receiver, meanings are generated and shared. The ideas discussed herein are the result of a study carried out with young students enrolled in the first year of High School in four schools: two public schools and two private schools. During the research they answered a questionnaire, participated in classroom discussions and in focal groups. The aim here, therefore, is to discuss what is generated in the reception, which content is relevant, with whom they are shared and how the school, as a space for socialization and learning, participates in this process.

Keywords: Youth. Teens. Media. School.

\section{PARTICIPER AVEC LES JEUNES ET LES ADOLESCENTS D'UNE EXPÉRIENCE DE RAPPROCHEMENT AVEC LE MONDE DES ADULTES: LE DÉFIS DE L'ÉDUCATION}

RÉSUMÉ: Cet article aborde les relations que les jeunes apprenants entament avec le système des médias. Entièrement capables de maîtriser les technologies des médias, ils se déplacent entre médias et intra médias avec une facilité absolue, avec de l'intimité quotidienne. Il se produit donc que toutes les technologies de l'information et le contenu fournis agissent comme médiateurs et intervenants de réalités. À l'autre extrémité, dans le domaine de la réception, il y a un destinataire avec une histoire et inséré dans un contexte culturel différent. Cela signifie qu'il y a un processus de construction de la réalité dans les centres émetteurs, une déconstruction de l'acte de réception et de nouvelles versions reconstruites à partir de la réception et des interactions avec des groupes sociaux. De cette confrontation entre contenus multimédias et une réalité historique-culturelle du récepteur on voit apparaître des significations. Ainsi, on se propose à discuter ce qui est établi à la réception, quels en sont les contenus pertinents, avec qui ils sont partagés et comment l'école, en tant qu'espace de socialisation et d'apprentissage, participe à ce processus.

Mots-clés: Jeunes. Adolescents. Médias. École.

\section{Introdução}

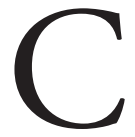

om o suporte de sofisticados sistemas tecnológicos e inesgotáveis fontes de informações "mundos" são construídos e realidades são, a todo instante, editadas. São processos que nos emocionam, alimentam 
nosso imaginário, fornecem significados e intervêm em nossa reflexão. As mídias fornecem referências e modelos para a formação de juízos acerca do nosso cotidiano e da realidade do mundo. Juntamente com a escola e a família, os meios de comunicação social tradicionais e as tecnologias de informação constituem fontes de saber e de socialização, especialmente de adolescentes e jovens. Entretanto, os "mundos midiáticos" são construídos e controlados por conectores com poderes para escolher, produzir e distribuir informações, segundo critérios técnicos, crenças e ideologias. (CASTELLS, 2001) Com isso, temos uma infinidade de informações postas e, muitas vezes, compreendidas como "espelhos" da realidade. No interior do próprio sistema midiático encontra-se uma pluralidade de ideias que exigem do telespectador/leitor/ouvinte ${ }^{1}$ reflexóes apuradas: a rigor, uma atividade complexa até para o usuário experimentado. A desenvoltura e a habilidade com as quais os adolescentes e os jovens manipulam as tecnologias midiáticas provocam uma primeira questão: estariam eles igualmente aptos a lidar com os conteúdos percebidos sem a ajuda dos que estão ao seu redor?

A escola, tradicionalmente, mantém-se como uma das instituições mais próximas do cotidiano dos adolescentes e dos jovens. É, embora não hegemônica nem a única, ainda um fórum de debates, de reflexão, de muitas vozes. A escola não é apenas um centro de ensino e aprendizagem, mas é, também, um espaço mediador de informaçóes sobre a realidade. Os conteúdos midiáticos estão nas conversas dos alunos, nos exemplos de professores, nas tarefas escolares e são utilizados como recursos de apoio à aprendizagem e como condição para a ascensão escolar, como é o caso dos temas contemporâneos solicitados nos exames vestibulares. Esta ubiquidade dos conteúdos midiáticos nas escolas e no interior da sala de aula constitui um desafio para o sistema escolar e faz emergir outra questão: cabe à escola a tarefa de auxiliar seus alunos a selecionar e inter-relacionar as informaçóes disponibilizadas no universo midiático?

$\mathrm{Na}$ ausência ou impossibilidade, cada vez mais crescente, de os pais acompanharem seus filhos tanto na escola onde estudam como em suas vivências midiáticas, restam aos alunos e alunas valerem-se do próprio conteúdo midiático e contarem com a inventividade e posturas críticas de professores e colegas mais esclarecidos. Ao adolescente e ao jovem estão disponibilizados, no universo midiático, contextos infantis e adultos, os quais vivenciam e com os quais interagem e se articulam. As consequências desse movimento contínuo de adolescentes e jovens, entre e intra-mídias, em seu processo de desenvolvimento humano, não estão ainda totalmente compreendidas. Adolescentes e jovens não olham mais para o mundo ao modo dos olhares de geraçóes passadas, de nossos pais e, por certo, portam-se diferentemente do modo como hoje olhamos. Esse novo olhar cobra outra questão, esta proposta por Eliseo Verón (2004): como estão articuladas a produção e a recepção dos discursos midiáticos? 
Refletir a relação dos adolescentes e dos jovens estudantes com o universo midiático, os mundos que eles constroem e quem são aqueles que participam com eles desse processo, como amigos, familiares e professores, principalmente, constitui um desafio tão atual quanto o da mediação tecnológica em seu cotidiano. A questão, aliás, está menos nas tecnologias e mais nas interaçóes sociais. (MOREIRA, 2009) A relação do jovem-adolescente com o universo midiático é, a nosso ver, uma relação que o empurra para o mundo adulto, quando ele se torna, então, professor da família, consumidor potencial e símbolo cultural e o leva de volta à infância, à segurança do lar, para o ensinamento dos pais e às fantasias infantis, quando ele se converte na criança que não deixou de ser.

Por relação com o universo midiático, considero tanto o contato dos jovens e adolescentes com todos os artefatos tecnológicos de transmissão de informação, como com os conteúdos midiáticos. Entendo como sendo artefatos tecnológicos de transmissão de informações tanto as antigas mídias portáteis: um jornal, um livro, por exemplo, como as tecnologias de informação, conforme conceito atribuído por Castells (2001, p. 49): “[...] o conjunto convergente de tecnologias em microeletrônica, computação (software, hardware), telecomunicaçóes/radiodifusão e optoeletrônico [...]". Assim, quando falo em mídia, meios de comunicação e tecnologias de informação estou me referindo a um conjunto de meios eletrônicos e impressos que, com seus conteúdos, cumprem uma função mediadora da realidade no cotidiano dos jovens: televisão, cinema, vídeo, Internet, computador, jornal, revista, livro, CDs, MP3, MP4, aparelho celular, fotografias, cartazes, pôsteres, outdoor, entre outros. Ressalvo, porém, que a denominação "meios de comunicação", tradicionalmente utilizada para nomear veículos difusores de informaçôes jornalísticas e de entretenimento, está, conjuntamente com as novas tecnologias, aqui compreendida como mídias. Ocorre que todos os meios e conteúdos, em seu conjunto, da música a uma imagem na minúscula tela de um celular, da tela de um cinema a um slogan em um outdoor, ou do editorial de um jornal à telenovela, são utilizados na construção de mundos: são discursos da cultura.

Por este modo de pensar, a cultura midiática infiltra-se, mistura-se à educação formal. $\mathrm{O}$ encontro na escola de jovens e adolescentes integrados às diferentes mídias - eles levam para o ambiente escolar novos conhecimentos, ampliando a compreensão para além daquilo que era intencionado pelo professor - torna a sala de aula um campo de anunciação e réplicas, e a aula em um "acontecimento”. (GERALDI, 2004) Trata-se de uma evidência que, segundo Citelli (2006, p.7), "[...] transforma a sala de aula em um espaço cruzado por mensagens, signos e códigos que não se ajustam ou se limitam à tradição conteudística e enciclopédica que rege a educação formal [...]".

O meu interesse pelo que acontece no campo da recepçáo, a desconstrução das mensagens, o uso da contrapalavra ${ }^{2}$ enquanto modo de compreensão e 
os processos de reedição das informações percebidas no espaço social, no universo das interações, especialmente no ambiente escolar, tem origem em dois estudos desenvolvidos com alunos do ensino médio em Cuiabá, um em $1999^{3}$ e o outro em $2002^{4}$. No primeiro, os jovens estudantes se mostraram encurralados - sentimento de ser levado, empurrado, atropelado pelos meios de informação. No segundo, já com a iminência das novas mídias, surgem as possibilidades de escolhas enquanto o oposto do encurralamento. As informaçóes que os jovens estudantes do ensino médio acessam através dos meios de comunicação e como lidam com elas - a recepção da informação, a reedição e, depois, como compartilham, tornaram-se do meu interesse. Tanto a ideia de encurralado pelas mídias, como se as mídias fossem condutor e senhor, como a capacidade de manipular máquinas e escolher conteúdos, em meio a centenas de ofertas, trazem embutido, nesses processos, um duelo de conteúdos simbólicos entre os emissores de entretenimento e de informação e os seus receptores.

Este embate simbólico entre receptores e emissores permite experiências mediadas por máquinas ou pessoas. São experiências de fazer, de desfazer, de refazer e vivenciar, submetidas a um confronto implícito, oculto, entre os sistemas ideológicos estabelecidos e a ideologia encontrada em cada cotidiano, em cada um dos contextos estudados. (THOMPSON, 2009) Há nesse processo de escolhas de programas e de leituras, na recepção de informaçóes, na atribuição de significados, na experiência de "trocas simbólicas" 5 com outros sujeitos, inúmeras e distintas atividades envolvidas. Assim, a multiplicidade de ofertas de conteúdos midiáticos, as possibilidades de escolhas decorrentes não só da quantidade de ofertas de conteúdos, mas, sobretudo, do barateamento das tecnologias de acesso aos diferentes conteúdos, estão em uma confluência de cincos aspectos, cuja convergência, simultânea, tem especial relevância:

1. As transformações na sociedade decorrentes do fenômeno da globalização e do acesso às novas tecnologias de informação e da "comunicação-mundo" ${ }^{\prime}$;

2. A engenharia de construção de mundos que empreendemos a partir de nossa história e de nosso contexto social e cultural;

3. A onipresença dos meios de comunicação e das tecnologias de informação e os mundos que edificam a partir de escolhas que são feitas entre o que é noticiável ou não, entre o que é entretenimento ou não;

4. A constatação de que a escola não é mais a referência, o único e certeiro caminho para a aquisição de conhecimentos;

5. O tempo da adolescência, com suas transformações físicas e psicológicas, as atividades mediáticas que os jovens em seu tempo de "transitoriedade" empreendem e a confrontação familiar e social que assumem enquanto 
perseguidores incansáveis de liberdade, de autonomia e de poder de decisão.

Estes cinco elementos, conjugados, mostram a complexidade do envolvimento dos jovens e adolescentes com as mídias. Julgo oportuno considerar que o meu interesse pelo ambiente escolar se deve ao fato de que a escola, como nós a conhecemos hoje, ainda é um privilegiado espaço de relaçóes presenciais, de reflexóes, de interaçóes, de trocas. Por outro lado, vive-se hoje um tempo em que a responsabilidade pela educação e formação das crianças e jovens não é mais exclusiva das famílias, o que nos remete para a ideia de que o compromisso com a educação deve ser coletivo, já que os jovens e as crianças acenam e se articulam com as mudanças que a sociedade como um todo está lhes impondo, (ARROYO, 2004) E, seja focando a Educação pela sua vertente libertadora (FREIRE 1978; 1996; 2002), ou pela vertente da pedagogia crítica (McLAREN, 1997), ou pela proposta de resistência (APPLE, 1989), nós vamos nos defrontar com pedagogias que defendem escolas e educação democráticas, que propóem a formação de jovens cidadãos comprometidos com sua história, com sua cultura, um comprometimento que não se dá mais apenas face a face, mas mediado por tecnologias e produtores de conteúdos diversos.

Considerando, portanto, a onipresença dos meios de comunicação social e das tecnologias de informação (CASTELLS, 2001; THOMPSON, 1998; MATTELART, 1994) e a função mediadora que eles desempenham entre os jovens estudantes e os mundos por estes criados; considerando também os sistemas de escolhas do que é noticiável e do que é entretenimento a que se submetem os meios de comunicação (TRAQUINA, 1999; ALSINA, 1989; TUCHMAN, 1983) e os diferentes contextos onde os meios e as informaçôes são recebidos, propagam-se relaçóes de poder e de forças simbólicas (FOUCAULT, 2002; 2004; BOURDIEU, 2002; 2004; 2005), que se articulam e buscam se impor no interior de um agrupamento social. Este, por sua vez, e os sujeitos que o compóem, constituem o campo da recepção, o espaço onde, de fato, a comunicação se realiza. (SOUSA, 1995)

Os receptores das versóes divulgadas empreendem um processo de desconstrução, reconstrução e propagação de novas versóes, que expressam como se deu este confronto de forças. Dessa equação participam também a família e os amigos. A escola, o jovem a frequenta porque se acredita que nela ele pode ser educado para a aquisiçáo de conhecimentos essenciais para interpretar o seu momento presente e, com isso, delinear e alcançar o seu horizonte de futuro. Já que tanto o presente do jovem, como as suas aspirações de futuro têm forte presença das tecnologias de informação e dos meios de comunicação, com quem ele compartilha os mundos que constrói? 
Um caminho para se aproximar de algumas respostas é reconhecer o consumidor de mídias que habita o aluno e identificar as atividades midiáticas que empreende, não apenas pelos programas televisivos que consome ou pelas leituras que realiza em jornais, revistas ou Internet, mas, inspirado em Michel de Certeau (1994), especialmente por aquilo que ele "fabrica" com os conteúdos apreendidos, com quem ele compartilha as versóes que constrói e qual é o papel da escola nesse processo. Nesta direçáo, pode-se contribuir com os esforços que educadores e comunicadores empreendem para concretizar, na escola, a atividade reflexiva dos conteúdos midiáticos, como forma não apenas de inclusão do jovem na sociedade da informação, mas, sobretudo, como atividade que potencializa a sua capacidade de compreensão e de aproximação da realidade em que vive.

\section{Procedimentos Metodológicos}

Para discutir a relação dos jovens e adolescentes com as mídias, me beneficio da abordagem histórico-cultural. (VYGOTSKI, 1993; 2000; 2001; 2002; BAKHTIN, 2003; 2004; FREITAS, 2002) Por essa vertente metodológica reconhece-se no entorno, em seus aspectos sociais, culturais e históricos, as referências determinantes. Este trabalho discute resultados ${ }^{7}$ de uma pesquisa com 110 alunos do primeiro ano do Ensino Médio, de quatro diferentes escolas, duas em Poços de Caldas (MG), uma na cidade de São Paulo (SP) e outra na cidade de São José dos Campos $(\mathrm{SP})^{8}$. Para compreender a relação dos jovens com as mídias e a mediação da escola neste processo, realizamos uma descrição detalhada das escolas, dos aparatos tecnológicos de informação disponibilizados aos alunos, além de entrevistas com diretores, coordenadores pedagógicos e professores, cujas falas não estão neste trabalho contempladas. Aos alunos foi proposto um extenso questionário, com questóes abertas e fechadas. $\mathrm{O}$ segundo passo foi debater em sala de aula as respostas obtidas no questionário. Em seguida, tendo como critério a participação qualitativa no debate, foram selecionados oito integrantes de cada sala para o aprofundamento dos temas mais polêmicos. Este procedimento metodológico, que resultou na identificação e compreensão das recorrências, diferenças, coincidências e não coincidências, ajudou a olhar não apenas os passos do dançarino, ou da dançarina - aqui dos alunos e alunas, das famílias, da escola, dos meios de informação - mas os movimentos que explicam os passos que são dados. ${ }^{9}$

A escola 1 é privada, matutina, e frequentada por jovens que querem ingressar, a qualquer custo, em uma universidade pública de referência. Frequentam uma escola de sistema, cujo apostilado atende ao receituário da maioria dos cursinhos especializados em formar alunos aptos a realizar o vestibular. A escola 2 é pública, noturna, frequentada por filhos de famílias com pouco poder aquisitivo. Denominamos este grupo de "estudantes que trabalham". Estes alunos almejam 
uma universidade como forma de ascensão social, ainda que seja privada, uma vez que compreendem as dificuldades para a conquista de vagas em universidades públicas. O terceiro grupo, Escola 3, é privada, mantém atividades em tempo integral e seus alunos pertencem a famílias com alto poder de consumo. Para eles, o ingresso em uma universidade é um processo natural. É para lá que eles caminham, não importa se pública ou privada, se está localizada no Brasil ou não. É um caminho certo. Para o quarto grupo, alunos de uma escola pública noturna, a universidade não existe enquanto perspectiva de futuro. Para estes trabalhadores que estudam, desenvolver alguma atividade remunerada, no próprio bairro, é o desejo manifesto de futuro.

\section{Os desafios apresentados à escola}

Do trabalho empírico, quatro categorias emergiram como determinantes na relação dos jovens e adolescentes com as mídias: flâneur midiático, construtores de mundos, dupla vinculação e contrapalavras. Embora diferentes um do outro, os quatro grupos de alunos preferem estar mais com os amigos e menos com as mídias. Apesar disso, o consumo diário de diferentes mídias ultrapassa a média de quatro horas, mesmo para quem estuda em tempo integral ou trabalha o dia todo. ${ }^{10}$ Independente do grupo e das relações estabelecidas com familiares e instituições de ensino, a onipresença das mídias no universo jovem é determinante. Quando indagados sobre onde se informam e com quem compartilham as informações sobre o mundo, nas quatro escolas a TV e a escola são os principais espaços para obtenção de informaçóes. E os professores, ainda que com índices menores do que a família e os amigos, são interlocutores importantes quando o assunto é conversar sobre o que é noticiado. Dos 110 alunos das quatro escolas, 103 sabem o que acontece no mundo pela televisão, 93 tomam conhecimento na escola e 69 pela Internet. Os familiares dos alunos são os principais interlocutores quando o assunto é notícia. Dos 110 alunos, 89 são informados pelos pais, 83 pelos amigos e 77 pelos professores.

Nesta modernidade, em seu sentido atribuído por Giddens (2002), Comunicação e Educação tornam-se interdependentes, pois se trata de uma discussão que objetiva mostrar que essas duas áreas são, ao mesmo tempo, produto uma da outra. A escola, e não poderia hoje ser diferente, é um campo por excelência de ressonância das mídias: nesse ambiente, alunos e professores trocam, em uma relação face a face, diferentes versóes de mundo. E as versóes são construídas a partir e com a mediação das tecnologias de informação, dos meios de comunicação e da cultura. Neste sentido, o contexto histórico-cultural, onde as relaçóes se dão, atua de modo decisivo para impulsionar o potencial de desenvolvimento de 
uma pessoa. A experiência do conhecimento é histórica, cultural e social: tem a cumplicidade do coletivo.

As interações entre as pessoas, além de presenciais, estão também, ao modo de Thompson (1998), "mediadas" por tecnologias de informação e "quase mediadas" por meios de comunicação, que se encarregam, sob nossa autorização (outorgada quando a eles dedicamos audiência), de mostrar, a seu modo, o mundo em que vivemos. Dos acontecimentos veiculados não participamos. $\mathrm{A}$ nossa experiência difere daquele que detém a informação, que é quem nos conta o que houve. Não há mais entre o "narrador" e o espectador/leitor/ouvinte uma experiência comum. No entanto, esta interdependência entre a modernidade e os meios de comunicação não surge ao acaso, como fatalidade ou consequência natural da evolução humana.

O entrelaçamento das mídias com as instituições edificadas nas sociedades modernas comporta uma complexidade cuja compreensão plena requer admitir a relevância e a centralidade das mídias neste processo. (THOMPSON, 1998; 2009) Pensar a modernidade é entender "[...] o controle regular das relaçóes sociais dentro de distâncias espaciais e temporais indeterminadas [...]”. (GIDDENS, 2002 , p. 22) O controle em tempo e espaço indeterminados não se exerce senão graças às diferentes tecnologias de suporte aos sistemas de comunicação individual e social. A modernidade a que me refiro atribui ao indivíduo uma capacidade de transitar por diferentes saberes, estes alheios aos tradicionais ensinamentos da família, da escola e das religiôes. Isso requer do indivíduo uma formação heróica: "O herói é o verdadeiro tema da modernitê". (BENJAMIN, 1975, p.12) Ocorre que não há uma única modernidade, pois ela se apresenta de diferentes formas, em diferentes lugares e também de diferentes formas em um mesmo lugar.

Em tempo, não discuto aqui exatamente como a escola se relaciona com os conteúdos dos meios de comunicação e com as tecnologias de informação, mas, especialmente, como os alunos se relacionam com os meios e as tecnologias, os processos que empreendem tanto na escolha de emissores e de conteúdos, como nas reflexóes que realizam acerca do que viram, leram ou ouviram e a importância que atribuem à família, aos amigos e à escola, quando compartilham o conteúdo midiático. Concordo especialmente com Moran (1996) e Silverstone (2002), quando estes autores acentuam o caráter de encantamento que suscitam determinados conteúdos dos meios de comunicação, bem como o manuseio das tecnologias que os abarcam. As tecnologias, como já anteriormente abordado, não são descobertas do acaso, nem tão somente aparatos técnicos, mas resultantes de contextos histórico-culturais; estão submetidas a interesses econômicos e políticos e são usufruídas de diferentes formas, com diferentes possibilidades de acesso, o que nos remete, portanto, a diferentes facetas destas experiências. 
De fato, as experiências dos quatro grupos de estudantes no relacionamento com as mídias se distanciam quando o assunto é o ensino/aprendizagem e se aproximam quando tem relação com a vivência pessoal, com o tempo da adolescência. Os quatro grupos tanto obedecem a seus professores quando são instigados a pesquisar nas mídias, quanto os ignoram no modo de fazê-lo: bate-papos virtuais, ver televisão e navegaçóes inconfessáveis "tomam” o tempo de tarefas escolares de todos os grupos. Enquanto os dois grupos situados nos extremos (Escolas 3 e 4) admitem que dedicam pouco tempo às tarefas escolares, alguns integrantes até confessam que copiam trabalhos prontos e entregam aos professores; os grupos das Escolas 1 e 2 levam seus estudos mais a sério, pois são cobrados pela família, ao mesmo tempo em que a escola é para eles, efetivamente, um degrau importante para a ascensão social.

Outra questão importante é a centralidade da infância no universo midiático. A infância terminaria com o início da juventude? O tempo de juventude se alonga, porque o jovem vive um presente cada vez mais estendido? Sem os ritos de passagem que marcaram, no passado, as trajetórias da infância para o mundo adulto, adolescentes e jovens encontram no universo midiático uma importante referência para o seu crescimento, seu desenvolvimento humano e aquisição de conhecimentos. Assim, jovens e adolescentes se submetem a uma dupla vinculação em seus intensos fluxos aos mundos, adulto e infantil. Em outro sentido, cada um de nós edifica mundos. (GOODMAN, 1995; BERGER; LUCKMANN, 2002) Nós construímos realidades em nossos cotidianos a partir das realidades construídas pelos sistemas midiáticos. $\mathrm{O}$ receptor jovem, adolescente, principalmente, é um sujeito, tem a posse de sua vontade e de seus desejos, mas transita em uma cultura midiática cujas estratégias de sedução, persuasão, encantamento e consumo ocupam praticamente todo o campo da recepção.

Os jovens caminham intra e entre mídias. Fazem isso folheando revistas e jornais, zapeando na televisão e navegando na Internet. Mas o caminhar nas mídias envolve riscos. $\mathrm{O}$ estado de movimento permite experiências de escapes em trajetos indesejados e o aprisionamento do olhar pelas imagens sedutoras. Os alunos das quatro escolas mudam de canal quando a programação incomoda, movem o dial quando a música não agrada, e aqueles que tem acesso à internet navegam simultaneamente em diferentes sites. Este caminhar é feito com desenvoltura, com a segurança de quem sabe o que faz. No entanto, a ubiquidade das mídias e as múltiplas realidades encontradas no sistema midiático levam o jovem a se portar como um adulto, que escolhe o que convém. Alcança o mundo adulto quando quer, mas, uma vez estando lá, nega ou desconhece as responsabilidades do mundo adulto e se recolhe na segurança do casulo infantil. Andar é não ter um lugar. Os alunos das quatro escolas mostram-se atraídos pelo que veem e pelo que ainda não viram. Isso tanto os leva a ficar em um canal, em uma página, como é condição para mudar. $\mathrm{O}$ que os diferencia são os lugares que ficam e o que esperam ver. 
Enquanto os alunos da Escola 3 conversam pela rede com amigos de diferentes estados do Brasil e até com amigos de outros países e assistem a canais de TVs fechadas em inglês, os alunos da Escola 4 preferem programas populares em emissoras de rádios e de TVs abertas. No entanto, todos têm em comum a atração pela notícia fácil, curta, sobre a vida de seus atores midiáticos preferidos. Alunas, principalmente das escolas 1 e 3, procuram revistas semanais de interesse geral, mas ocupam o tempo dedicado à leitura com notinhas sociais e informaçóes sobre artistas do cinema e da televisão.

Os jovens adolescentes encontram notícias, de todo e qualquer assunto, em todos os fluxos midiáticos. A notícia é hoje uma mercadoria, feita para atender simultaneamente a todos os tipos de público. (MEDINA, 1988) Os jovens das quatro escolas aceitam que aquilo que viram e ouviram é o que realmente aconteceu. O que torna isso possível são os recursos tecnológicos disponíveis, a eficiência da mediação dos atores midiáticos e a confiança depositada no meio de comunicação, quando dedicamos a ele a nossa audiência. $\mathrm{O}$ modo como a notícia é produzida e encontrada repetidas vezes, no mesmo enfoque, por diferentes canais, de fato parece espelhar a realidade: um canal reafirma a veracidade da informação contida no outro. Não satisfeitos com a audiência concedida a novelas, filmes, programas de auditório, programas esportivos e policiais, principalmente, os jovens das quatro escolas "perseguem" seus atores midiáticos e os sonhos que representam nas revistas, nos telejornais e nos programas de fofocas. E tornam estes temas o centro das conversas interpessoais.

No início do século passado Benjamin (2002) antecipou, diante da crescente industrialização de brinquedos, o avanço do capitalismo sobre as crianças. Hoje, as novas tecnologias de informação e de entretenimento ocupam totalmente o mundo infantojuvenil, mas não apenas em seu aspecto instrumental, utilitário. Está, especialmente, na gestação de mundos simbólicos. Algumas consequências da inserção das tecnologias mediáticas em nosso cotidiano já estão documentadas em numerosos estudos, como, por exemplo, as novas formas de compreensão depois do audiovisual e dos computadores. (BABIN; KOULOUMDJIAN, 1989) Hoje, ao mesmo tempo em que adolescentes e jovens, inclusive crianças, impóem suas escolhas aos adultos, sobretudo no que diz respeito ao consumo, a condição infantil os coloca em situação de dependência das vozes de seus pais e de outros representantes.

Com a chegada da adolescência vem também o período de juventude. No Brasil há uma "imprecisão" na utilização dos termos juventude e adolescência: ou são distintos ou estão superpostos. (FREITAS, 2005) Apesar disso, ambos são complementares. Alguém com idade entre 14 e 16 anos, por exemplo, está, seguramente, na fase da adolescência: é um "jovem-adolescente” vivendo como um adulto, mas ainda na infância, pois se já é capaz de fazer escolhas de consumo ou de definir sua futura profissão, ainda é dependente para obter alimentos, 
para matricular-se em uma escola, por exemplo. É um jovem-adulto vivendo a sua infância: isso é tão contraditório em sua lógica, quanto verdadeiro em suas circunstâncias.

O que me parece pertinente aqui mais uma vez registrar é que o "jovem-adolescente” encontrado nas quatro escolas tem uma existência fortemente marcada por fluxos: da infância ao mundo adulto e vice-versa. Estas são trajetórias que ele simultaneamente percorre com o suporte das tecnologias de informação e dos meios de comunicação. Ao acompanhar os fluxos midiáticos o jovem edifica conceitos, e o faz com apoio dos que o rodeiam: amigos, familiares, professores, colegas de classe e, naturalmente, os atores midiáticos. O “jovem-adolescente” e todos os que estão ao seu redor também constroem seus conceitos de mundo com a ajuda de quem está ao redor de todos: as mídias. Esta capacidade dos meios de comunicação de produzir fluxos da infância ao mundo adulto e arrolar o jovem nesta trajetória pode ser compreendido pelas falas dos jovens quando escolhem os programas por diversão e entretenimento, mas são, seja nas propagandas ou plantáo de notícias, puxados para o mundo adulto, como neste depoimento de Vicente, da Escola 1: "Interessante, mas é isso que a Mídia impóe para a gente, que é importante, só que a mídia, na verdade, é um meio de entretenimento para a gente. A gente não tem que saber que a mulher morreu, mas é bom saber, entendeu ${ }^{11}$ ?"

Dada à ubiquidade e onipresença dos meios, assim como pelo modelo de produção e distribuição da informação, este sistema assume papel relevante no entendimento que temos de realidade. E o real, "[...] é aquilo que, em cada lugar, a referência a um outro faz acreditar [...]”. (CERTEAU, 1994, p. 289) Um relato para parecer verossímil precisa estar ancorado no que se mostra, no que é visível. (CERTEAU, 1994) Uma pessoa tem como certo que o real é aquilo que ela conhece como realidade. E questionar a realidade é algo impensável no cotidiano, pois a própria existência no mundo é a prova de que a realidade existe. (BERGER; LUCKMANN, 2002) Nenhum estudante, das quatro escolas, no questionário, colocou em dúvida a veracidade das informaçóes divulgadas pelos meios de comunicação. Ao contrário. Agora, dúvidas, medos, insegurança, incertezas apareceram no debate em sala de aula e foram reafirmadas nas discussóes com grupos menores. Estão presentes em suas conversas cotidianas.

Os meios de comunicação e as tecnologias de geração, armazenagem e transmissão de informaçóes são sistemas complexos que emergem do interior da sociedade e com ela mantém uma relação dialógica, no sentido atribuído por Bakhtin, e semiótica, no sentido atribuído por Vygotski. O que é comum em todos os espaços de armazenagem, de geração e de transmissão de informações é a condiçáo de arena. Nela, podemos encontrar as contradiçóes da sociedade. Enquanto consumidores de mídias, as crianças, os adolescentes e os jovens estão ali também inseridos, não em uma condição passiva, mas de embate, de confronto. 
Um aspecto do debate em sala de aula realizado na Escola 2 pode muito bem ilustrar este pensamento. A maioria dos alunos concordava com a opinião defendida por alunos e alunas de que a novela juvenil Malhação mostra a realidade do jovem, pois discute temas sobre sexo, namoro, drogas entre outros de interesse desta faixa etária. O conceito do programa, nas palavras de Luiza, com a concordância da sala, era que o programa tem a "cara" do jovem, "[...] fala sobre a gente da nossa idade, os nossos problemas". Em dado momento, dois alunos, Ricardo e Messias, até então calados, intervém e subvertem completamente o debate: “[...] nem sempre não tem não. Malhação, a vida deles é ir da escola pro [sic] clube, do clube pra casa”, diz Ricardo. E Messias pergunta: "E o trabalho?” Ricardo complementa: "É, e o trabalho? Ce (você) não vê eles trabalhando... Minha vida não é assim não".

Com a ocupação da recepção pelas forças estratégicas orquestradas na emissão, o jovem receptor converte-se em inventor de táticas. São, portanto, com táticas próprias de enfrentamento que os jovens lidam com as mídias. O cotidiano é a "arena" (BACCEGA, 1996) de embates entre as diferentes forças. Para participar desse embate, o "jovem-adolescente" se nutre de ferramentas contidas nas próprias tecnologias, como o controle remoto, o mouse, por exemplo, e gera, na própria relação com os conteúdos midiáticos, com amigos, familiares e professores, contrapalavras de confronto. Convertido em voyeur da informação e flâneur das tecnologias mediáticas, o jovem mobiliza-se com maior ou menor contundência entre e intra-mídias.

Eles movimentam-se nos mundos das mídias com ouvidos, olhos e mãos. Mãos, olhos e ouvidos acionam o celular. Com as mãos, os jovens folheiam jornais e revistas, clicam o mouse e apertam o teclado do computador; com as máos acionam o controle remoto da televisão e do vídeo. Com os olhos "correm" atrás das palavras e das imagens. Zielinski (2006) busca conexão entre as tecnologias mediáticas, como as conhecemos hoje, e as ideias e meios técnicos remotos: ideias e máquinas que emprestaram à visão e à audição movimentos que extrapolaram os contextos originais. Aspectos mostrados por Zielinski (2006), em Empédocles, Della Porta e Krasnokutskij (Avraamov), e a fusão dos olhos e das mãos na construção de conhecimento (SAMSONOW, 2007), motivados pela relação que os objetos de mediação desenvolvidos ao longo da história tiveram com os sentidos humanos, nos convidam hoje a pensar a relação dos "jovens-adolescentes" com as mídias.

Considerando a inserção dos “jovens-adolescentes” em universos simbólicos múltiplos, e as ausências mais ou menos acentuadas da escola e da família nesse processo, devemos questionar como eles recebem os significados atribuídos às palavras pelos seus interlocutores: "A palavra está sempre carregada de um conteúdo ou de um sentido ideológico ou vivencial. É assim que compreendemos as palavras e somente reagimos àquelas que despertam em nós ressonâncias 
ideológicas ou concernentes à vida”. (BAKHTIN, 2004, p. 95) Ao dizer palavras, aquele que fala nelas embute valores e juízos. Esses são atributos do enunciador, o que torna a linguagem um instrumento do jogo ideológico. O sistema midiático é também a arena de um confronto simbólico entre forças que o estudante, pela pouca idade, ainda não compreende plenamente como se dá e como se processa.

Mas, independente do que é compreendido pelo "jovem-adolescente", o ato da compreensão, seja ela qual for, é sempre ativo, pois a compreensão "deve conter já o germe de uma resposta”. (BAKHTIN, 2004, p.131) Podem-se tomar como exemplo alguns programas de televisão, nos quais os apresentadores portam-se à moda de um diálogo face a face. A informalidade da fala e o modo como se dirige ao telespectador criam uma situação íntima, como se o apresentador estivesse lado a lado com o telespectador, o que evidentemente não ocorre. Se o tema está no campo de interesse do telespectador ou contenha significaçóes pertinentes ao seu cotidiano, ele se apossa do discurso e o reconfigura com as suas contrapalavras e lança-se com este repertório a outro diálogo: com os amigos, com outros atores midiáticos e, menos frequentemente, com seus familiares e professores. (MOREIRA, 2008)

As relações que os “jovens-adolescentes" estabelecem com o sistema midiático trazem profundas implicaçóes no entendimento que eles formam da realidade. Entretanto, o sistema midiático não é uníssono. Há muitas mídias tanto no sentido de diversidade de canais como no sentido das escolhas que são feitas para entreter e informar. De um lado, os mundos concebidos na produção da informação e do entretenimento e de outro um mundo pessoal, único, singular, do receptor, porém interdependente de outros mundos, pertencente a um universo social cujos sujeitos mais próximos têm especial relevância em suas escolhas midiáticas. Desse encontro, do emissor com o receptor, é produzido algo novo, cuja ressonância tem especial vínculo com as pessoas que ocupam o entorno do jovem-adolescente. Em outros termos, o novo decorrente do fenômeno contido na audiência tem sua reflexão e propagação regulada pelas interações sociais e midiáticas que os jovens estabelecem.

A discussão em pequenos grupos trouxe depoimentos que podem reafirmar a importância da escola na relação dos jovens com as mídias. Com base em sua experiência de convivência com diferentes fluxos midiáticos, Kátia, da Escola 2, sugere a existência nos conteúdos de algo que aciona o prazer, que a impede de buscar informações mais úteis. Já Jurema, da Escola 1, acredita na existência de um processo que atua em seu cérebro, que a desarma de sua condição de sujeito, deixando-a momentaneamente sem ação, como se fosse uma pessoa viciada. Tanto nos debates em sala de aula, quanto nas discussóes em grupos, os alunos e alunas das quatro escolas reclamam da falta de debates sobre os meios e de conversas sobre fatos e sistemas informativos. 
Paradoxalmente, ao mesmo tempo em que a escola é um centro de gestação e propagação de conteúdos midiáticos, isso se dá menos por iniciativa da instituição e mais pela ubiquidade dos meios. Em outras palavras, não é a escola em seu espaço de construção de saber quem ordena e enfatiza conteúdos midiáticos pela sua relevância no contexto dos alunos, mas são os meios, a partir do que constroem em seus centros produtivos, que determinam no espaço escolar o que deve ser ou não enfatizado e ordenado. Com isso, muitas vezes sem o suporte da família e sem a participação da escola, ao modo de Goodman (1995), os jovens-adolescentes compóem e decompóem realidades, suprimindo, complementando e deformando. Quando a jovem Maria, da Escola 2, no debate em sala de aula, diz que assiste a programas policiais porque acredita que se algo ocorrer com a mãe dela, durante o trabalho, é por meio deste tipo de programa que ela ficará sabendo, ela está, por certo, construindo "outro mundo", pois a cidade dela é pacata, sem registros de balas perdidas e assassinatos, casos frequentes em grandes cidades.

A desenvoltura com a qual o jovem-adolescente transita entre e intra-mídias oculta medos e incertezas que surgem em toda caminhada. Tanto oculta a fragilidade de um caminhar solitário, sem o suporte de adultos mais esclarecidos, como fortalece a certeza de que ele tudo pode, tudo sabe. Esse talvez seja o paradoxo mais perverso com que o "jovem-adolescente" se vê envolvido: promessas de liberdade, acolhimento, proteção, sucesso e diversão atuam como mecanismos proibitivos para as tentativas de fugas deste modelo contraditório. Ao modo de Postman (1999), para quem a infância ainda existe porque as crianças insistem em vivê-la, apesar do adulto dela tentar arrancá-la, o "jovem-adolescente" ainda busca, preferencialmente, no outro, no contato face a face ou virtual, as trocas com as quais ele forma as suas contrapalavras e forja sua identidade. Aconchegar-se dele, para participar com ele dessa experiência de aproximação com o mundo adulto, talvez seja o maior desafio da Educação.

\section{Notas}

1. Considero, na caracterização de um leitor, as três definiçôes de leitores propostas por Lucia Santaella (2004, p. 31): o leitor "Contemplativo, Meditativo" e silencioso da leitura de livros; o leitor "Movente, Fragmentário" dos chamados meios de comunicaçáo, leitor de diferentes linguagens; e o leitor "Imersivo, Virtual", um tipo de leitor[...] "que navega entre nós e conexóes alineares pelas arquiteturas líquidas dos espaços virtuais [...]".

2. Contrapalavra, para Mikhail Bakhtin, é a oposição “à palavra do locutor”, é o nascedouro da compreensão. Diz Bakhtin (2004, p.132): "A cada palavra da enunciaçáo que estamos em processo de compreender, fazemos corresponder uma série de palavras nossas, formando uma réplica. Quanto mais numerosas e substanciais forem, mais profunda e real é a nossa compreensão [...]”. Portanto, para Bakhtin, não há como compreender sem realizar, simultaneamente, uma operação de avaliação, de onde vem a réplica que nos leva à compreensão. Já a possibilidade de compreensão aumenta com o aumento de palavras dispostas e preparadas para a contrapalavra. Sáo palavras que não vem senão do diálogo com os outros. Uma vez recebidas, as palavras são um pouco de todos, mas a contrapalavra pertence à "singularidade de cada sujeito", da compreensão que pôde empreender. (GERALDI, 
2002)

3. MOREIRA, B. D. Esqueceram de Mim. Eles só pensam nos meus pais. O jornal e o jovem: um estado de caso com estudantes de Cuiabá. 2000. Dissertação (Mestrado em Comunicação) Escola de Comunicação e Artes, Universidade de São Paulo, São Paulo, 2000.

4. Estudo desenvolvido com alunos da Universidade Federal de Mato Grosso.

5. Ver as obras de Pierre Bourdieu (2002, 2004 e 2005).

6. Comunicação-Mundo é um conceito de Armando Mattelart (1994). O autor expressa, ao mesmo tempo, a amplitude adquirida pela comunicação, em caráter planetário, e a suas especificidades em diferentes países, o que torna este processo desigual e excludente.

7. Estudo completo, defendido como tese de doutorado na Alemanha, junto à Faculdade de Educação da Universität Siegen. (MOREIRA, 2008)

8. Para selecionar as escolas e identificar o poder de consumo das famílias dos alunos das quatro escolas, foi utilizado o Critério Brasil. Na escola 1, a maioria dos alunos pertence aos grupos de consumo B1, B2 e C1. Na escola 2, a maioria pertence aos grupos de consumo B2 e C1. Na Escola 3, a maioria pertence ao Grupo A e na escola 4 a maioria pertence aos grupos C1, C2.

9. Birdwhistell (1994, p. 320-321) observou bailarinos de salão para definir um bom bailarino. As bailarinas disseram que "[...] el buen bailarín era aquel que sostenía con firmeza a su pareja y la dirigía con vigor [...]". Já os homens disseram que "[...] la buena bailarina debia tener un paso ligero y ser capaz de seguir inmediatamente [...]". Mas foi a partir do estudo dos movimentos que permitiu definir: "[...] la buena bailarina era en realidad la que sabia dirigir la danza y que el buen bailarin era el que sabia presentir el movimiento que iba a seguir [...]".

10. A pesquisa mostrou que a Internet, para aqueles que a possuem, sobretudo nas Escolas 1 e 3, é utilizada para a continuação de conversas interrompidas com o término do horário escolar.

11. Refere-se ao noticiário sobre a morte de freira norte-americana Dorothy Stang.

\section{Referências}

ALSINA, M. R. La Construcción de la Noticia. Barcelona: Paidós, 1989.

APPLE, M. W. Educação e Poder. Porto Alegre: Artes Médicas, 1989.

ARROYO, M. G. Imagens Quebradas: trajetórias e tempos de alunos e mestres. Petrópolis: Vozes, 2004.

BABIN, P.; KOULOUMDIJAN, M. Os Novos Modos de Compreender. Trad: Maria Cecília Oliveira Marques. São Paulo: Ediçóes Paulinas, 1989.

BACCEGA, M. A. O Campo da Comunicação e os Estudos de Consciência Verbal. Revista Logus, ano 3, n. 4, p. 25-29, 1996.

BAKHTIN, M. Estética da Criação Verbal. São Paulo: Martins Fontes, 2003.

BAKHTIN, M. (Volochinov). Marxismo e Filosofia da Linguagem. São Paulo: Hucitec, 2004.

BENJAMIN, W. A Modernidade e os Modernos. Trad: Heindrun Krieger Mandes da Silva, Arlete de Brito e Tania Jatobá. Rio de Janeiro: Tempo Brasileiro, 1975. 
BENJAMIN, W. Reflexóes Sobre a Criança, o Brinquedo e a Educação. São Paulo: Duas Cidades e Editora 34, 2002.

BERGER, P. L.; LUCKMANN, T. A Construção Social da Realidade: Tratado de Sociologia do Conhecimento. 21. ed. Trad: Floriano de Souza Fernandes. Petrópolis: Vozes, 2002.

BIRDWHISTELL, R. L. Entrevista a Ray Mac Dermott. In: WINKIN, Y. (Org.). La Nueva Comunicación. 4a. ed. Barcelona: Editorial Kairós, 1994, p. 311-322.

BOURDIEU, P. A Produção da Crença: contribuição para uma economia dos bens simbólicos. São Paulo: Zouk, 2002.

. O Poder Simbólico. 7a. ed. Rio de Janeiro: Bertrand Brasil, 2004. tiva, 2005.

A Economia das Trocas Simbólicas. Organização: Sergio Miceli. São Paulo: Perspec-

CASTELLS, M. A Sociedade em Rede. A era da informação: economia, sociedade e cultura. v. 1, 5a. ed. São Paulo: Paz e Terra, 2001.

CERTEAU, M. de. A Invenção do Cotidiano. 1. Artes de Fazer. Petrópolis: Vozes, 1994.

CITELLI, A. A Linguagem entre a Comunicação e a Educação. Comunicação \& Educação, ano XI, n.1. São Paulo: CCA/ECA/USP: Paulinas, jan./abril, 2006, p. 7-11.

FICHTNER, B; FREITAS, M. T.; MONTEIRO, R. Kinder und Jugendliche im Blick qualitativer Forschung. Oberhausen: Athena-Verlag, 2003.

FOUCAULT, M. Vigiar e Punir. 25a. ed. Petrópolis: Vozes, 2002.

2004.

. A Microfisica do Poder. 19a. ed. Org. Roberto Machado. Rio de Janeiro: Graal,

FREIRE, P. Educação como Prática da Liberdade. 8a. ed. Rio de Janeiro: Paz e Terra, 1978.

. Pedagogia da Autonomia: saberes necessários à prática educativa. 28a. ed. São

Paulo: Paz e Terra, 1996.

. A Importância do Ato de Ler: em três artigos que se completam. 43a. ed. São Paulo: Cortez, 2002.

FREITAS, M. T. de A. A Abordagem Sócio-histórica como Orientadora da Pesquisa Qualitativa. Caderno de Pesquisa, n. 116, 2002, p. 21-39. Disponível em: <http://www.scielo. br/pdf/cp/n116/14397.pdf $>$. Último acesso: dezembro de 2010.

FREITAS, M. V. de (Org.). Juventude e Adolescência no Brasil: referências conceituais. São Paulo: Ação Educativa, 2005. Disponível em: <http://www.acaoeducativa.org >. Acesso: 18.11.2006.

GERALDI, J. W. Aula Como Acontecimento. Aveiro, Portugal: Universidade de Aveiro, 2004.

. Leitura: uma Oferta de Contrapalavras. Educar em Revista, v. 20, p.77-85, 2002.

Disponível em: <http://ojs.c3sl.ufpr.br/ojs2/index.php/educar/article/view/2099/1751>.

Acesso em abril de 2011. 
GIDDENS, A. Modernidade e Identidade. Trad: Plinio Dentzien. Rio de Janeiro: Jorge Zahar Ed, 2002.

GOODMAN. N. Modos de Fazer Mundos. Trad. Antonio Duarte. Porto: Ediçóes Asa, 1995.

MCLAREN, P. A Vida nas Escolas: uma introdução à pedagogia crítica nos fundamentos da educação. 2a. ed. Porto Alegre: Artes Médicas, 1977.

MATTELART, A. Comunicação Mundo: história das idéias e das estratégias. 2a. ed. Petrópolis: Vozes, 1994.

MEDINA, C. Notícia, um Produto à Venda: jornalismo na sociedade urbana e industrial. 2a. ed. São Paulo: Summus, 1988.

MORAN, J. M. Novas Tecnologias e o Reencantamento do Mundo. Revista Tecnologia Educacional, v. 123, n. 126, set.-out., 1996, p. 24-26.

MOREIRA, B. D. Die Augen des Voyeurs und die Finger des Flâneurs: Brasilianische Jugendliche und ihre Rekonstruktionen der Realität durch Medien. 2008. Tese de Doutorado em Educação - Universität Siegen, 2008. Disponível em: <http://dokumentix. ub.uni-siegen.de/opus/volltexte/2008/375/index.html>.

Periferia e Internet: a questão está menos nas tecnologias e mais nos relacionamentos sociais. In: BENITES, M. et al. Janelas para o Mundo II: narrativas em tempo de Internet: pesquisas, pesquisadores e pesquisados. Porto Alegre: Casa do Arquiteto, 2009.

POSTMAN, N. O Desaparecimento da Infância. Trad. Suzana Menescal de Alencar Carvalho e Jose Laurenio de Melo. Rio de Janeiro: Graphia, 1999.

SAMSONOW, E. von. Os Sentidos Armados. A razão e seus instrumentos na Renascença. GHREBL - Revista de Comunicação, Cultura e Teoria da Mídia, n.9, março, 2007. Tradução: Martinho Junior. Disponível em: <http://revista.cisc.org.br/ghrebh9>. Último acesso em agosto, 2010.

SANTAELLA, L. Corpo e Comunicação. São Paulo: Paulus, 2004.

SILVERSTONE, R. Por Que Estudar a Midia? São Paulo: Edições Loyola, 2002.

SOUSA, M. W. de. Recepção e Comunicação: a busca do sujeito. In: (Org.). Sujeito, o Lado Oculto do Receptor. São Paulo: Brasiliense, 1995.

THOMPSON, J. B. A Mídia e a Modernidade: uma teoria social da mídia. Petrópolis: Vozes, 1994.

. Ideologia e Cultura Moderna. 8a. ed. Petrópolis: Vozes, 2009.

TRAQUINA, N. (Org.). Jornalismo: questóes, teorias e "estórias". 2a. ed. Lisboa: Veja, 1999.

TUCHMAN, G. La Producción de la Noticia: estudio sobre la construcción de la realidad. Barcelona: Editorial Gustavo Gili, 1983.

VERÓN, E. Fragmentos de um Tecido. Trad. Vanise Dresch. São Leopoldo: Unisinos, 2004. 
VYGOTSKI, L. S. Pensamento e Linguagem. São Paulo: Martins Fontes, 1993.

. Manuscritos de 1929. Educ. Soc., n. 71, Campinas, 2000, p. 21-44.

. A Construção do Pensamento e da Linguagem. São Paulo: Martins Fontes, 2001.

. A Formação Social da Mente: o desenvolvimento dos processos psicológicos superiores. São Paulo: Martins Fontes, 2002.

ZIELINSKI, S. Arqueologia da Mídia: em busca do tempo remoto das técnicas do ver e do ouvir. Trad. Carlos D. Szlak. São Paulo: Annablume, 2006.

Recebido em 28 de setembro de 2012.

Aprovado em 09 de outubro de 2012.

DOI: http://dx.doi.org/10.1590/ES0101-7330201564973 